Article

\title{
Effect of Fast-Growing Trees on Soil Properties and Carbon Storage in an Afforested Coal Mine Land (India)
}

\author{
Jitendra Ahirwal ${ }^{1} \mathbb{D}$, Adarsh Kumar ${ }^{2}$ and Subodh Kumar Maiti ${ }^{1, * \mathbb{D}}$ \\ 1 Ecological Restoration Laboratory, Department of Environmental Science and Engineering, \\ Indian Institute of Technology (Indian School of Mines), Dhanbad 826004, India; jk31bhu@gmail.com \\ 2 Institute of Natural Sciences and Mathematics, Ural Federal University, 620002 Ekaterinburg, Russia; \\ adarsh.biorem@gmail.com \\ * Correspondence: subodh@iitism.ac.in or skmism1960@gmail.com
}

Received: 31 July 2020; Accepted: 21 September 2020; Published: 23 September 2020

\begin{abstract}
Surface coal mining activities have numerous consequences on terrestrial ecosystems. Loss of soil and biomass carbon pool due to mining activities is a serious concern in the rapidly changing environment. We investigated the effect of fast-growing trees (Albizia lebbeck, Albizia procera, and Dalbergia sissoo) on soil fertility and ecosystem carbon pool after eight years of afforestation in the post-mining land of Jharia coalfield, India, and compared with the adjacent natural forest site. Significant differences in soil organic carbon (SOC) and total nitrogen (TN) stocks in afforested mine soil and natural forest soils were observed. Greater SOC stock was found under D. sissoo (30.17 Mg.C.ha ${ }^{-1}$ ) while total $\mathrm{N}$ stock was highest under A. lebbeck $\left(4.16 \mathrm{Mg} \cdot \mathrm{N} \cdot \mathrm{ha}^{-1}\right.$ ) plantation. Plant biomass accumulated $85 \%$ of the natural forest carbon pool after eight years of afforestation. The study concluded that planting fast-growing trees in post-mining lands could produce a promising effect on mine soil fertility and greater carbon storage in a short period.
\end{abstract}

Keywords: coal mining; reclamation; carbon and nitrogen stock; plant biomass; mine soil

\section{Introduction}

Globally, natural ecosystems are being degraded in an unparalleled way resulting in climate change, loss of biodiversity, and land degradation. Therefore, restoration of waste or degraded lands has gained global importance to conserve natural ecosystems and to combat the global climate crisis. According to the United Nations, "there has never been a more urgent need to restore damaged ecosystems than now" thus the United Nations General Assembly declared 2021-2030 as the decade for ecosystem restoration [1]. It aims to restore degraded land that delivers essential ecosystem services like enhancing food security, water supply, biodiversity, and mitigating climate change. Furthermore, the Bonn Challenge also committed to restoring $350 \mathrm{M}$ ha of land by the end of 2030 which not only helps to restore ecosystem services but also provides employment and generates economic growth [2]. Therefore, the restoration of former mine land can be an appropriate option to partially fulfill the goals of global land-use policies.

Mining is one of the most destructive activities in the natural ecosystem. At the same time, it has become an essential anthropogenic activity to fulfill human energy demand. Coal is the most abundant fossil fuel in India and fulfills 55\% of the energy demand of the country. India produced a total of 729.1 million tonnes of coal during 2019-2020, of which Coal India Limited (CIL) contributed $82.5 \%$ to its total production [3]. In India, more than $90 \%$ of coal has been extracted by surface mining methods that alter natural landforms and landscapes into disturbed territories. Surface mining removes the overburden material and inner partings located between the coal seam by drilling and blasting to 
reach the coal seam and excavate coal by a shovel-dumper combination and draglines. This results in the generation and disposal of a huge volume of fragmented rock that demonstrates poor physical characteristics, chemical properties, and normally nutrient deficiency [4-6]. It also causes deforestation and removal of carbon-rich topsoil that results in the release of carbon into the atmosphere $[7,8]$. In addition, loss of vegetation drastically disrupts the hydrological regime and causes a severe reduction in biodiversity. To minimize the adverse effect of mining, post-mining lands are reclaimed by engineered and biological reclamation techniques that provide an opportunity for sustainable land use.

Natural succession can be an attractive alternative to restore degraded land because of the low economic input, and the natural values of the spontaneously colonized areas are high [9]. Moreover, plants grown on them are more adaptable to environmental stress. However, natural or spontaneous succession is not suitable for hostile and extreme environmental conditions experienced by the post-mining ecosystems. Therefore, afforestation using regional flora is a much faster method and provides a great chance to introduce a variety of the high biomass plant and tree species which can phytosequester much more carbon than the natural ones and could help to accumulate soil organic matter (SOM) and increase soil organic carbon (SOC) storage [10-12]. Albizia lebbeck, Azadirachta indica, Dalbergia sissoo, Leucaena leucocephala, Heterophragma adenophylum, Melia azedarach, and Tectona grandis have been predominantly used for afforestation of mine-degraded lands in India. The sequestered SOC in post-mining sites has a positive effect on the soil quality, soil fauna, its diversity, and vegetation growth [11]. However, the development of the post-mining ecosystem and acceleration of the soil-forming process can vary with the type of treatment.

Soils store $1500 \mathrm{Pg}$ of organic carbon and $945 \mathrm{Pg}$ of inorganic carbon in the top 1-m depth, whereas atmosphere holds $750 \mathrm{Pg}$ of carbon, and phytomass stores $610 \mathrm{Pg}$ of carbon [13,14]. At the same time, a range of soil $\mathrm{CO}_{2}$ efflux has been reported that varies from 72.5 to $98 \mathrm{Pg} \cdot \mathrm{C} \cdot \mathrm{yr}^{-1}$ [15-17], which confirms soil is an important carbon source and/or sink in the terrestrial ecosystem. Surface mining activities remove fertile topsoil and subsoils that potentially act as carbon storehouses. Although reclamation activities reduce soil carbon loss to some extent, they are time-consuming and challenging. A range of reclamation practices such as topsoil application, selective plantation, use of chemical fertilizer, microbial agents, biochar, industrial or domestic waste, and sewage sludge has been reported to enhance soil carbon pool [18,19]. Out of these, afforestation/reforestation is widely used to restore mine land, but the selection of appropriate tree species is essential. The introduction of leguminous trees and grass-legume association enhances the nutrient content, and their litter below and above the soil enhances the microbial activity and rapid soil formation resulting in elevated carbon sequestration in multiple mine sites [20,21]. A multi-purpose tree plantation on former mine land also increases soil quality and ecosystem carbon pool along with the age of revegetation [22-25]. We hypothesized that the introduction of fast-growing trees with an appropriate mix can accelerate the recovery of mine-degraded land and increase carbon storage in the post-mining ecosystem. The objectives of this study were to (i) assess the effect of planting Albizia lebbeck (L.) Benth, Albizia procera (Roxb.) Benth, and Dalbergia sissoo Roxb on soil properties and carbon stock in post-mining land, and (ii) estimate ecosystem carbon stock of the mine land after eight years of afforestation and its comparison with the natural forest site. We anticipated that the outcome of this study may help select plant species for afforestation of former mine sites.

\section{Materials and Methods}

\subsection{Study Area}

The study area was located at the reclaimed mine lands of Jharia coalfields of Bharat Coking Coal Limited (BCCL), Jharkhand, India. The study sites were geographically located between $23^{\circ} 49^{\prime} 0.63^{\prime \prime}-23^{\circ} 38^{\prime} 36^{\prime \prime} \mathrm{N}$ and $86^{\circ} 08^{\prime} 49^{\prime \prime}-86^{\circ} 25^{\prime} 54^{\prime \prime} \mathrm{E}$, at an altitude of $200-250 \mathrm{~m}$ above sea level (Figure 1). The area experienced a humid subtropical climate with a mean annual temperature of $27^{\circ} \mathrm{C}$ and received mean annual precipitation of $1400 \mathrm{~mm}$, of which the southwest monsoon contributed 
$80 \%$. The mean temperature was higher in April, May, and June, and the greater precipitation was received in July, August, and September.
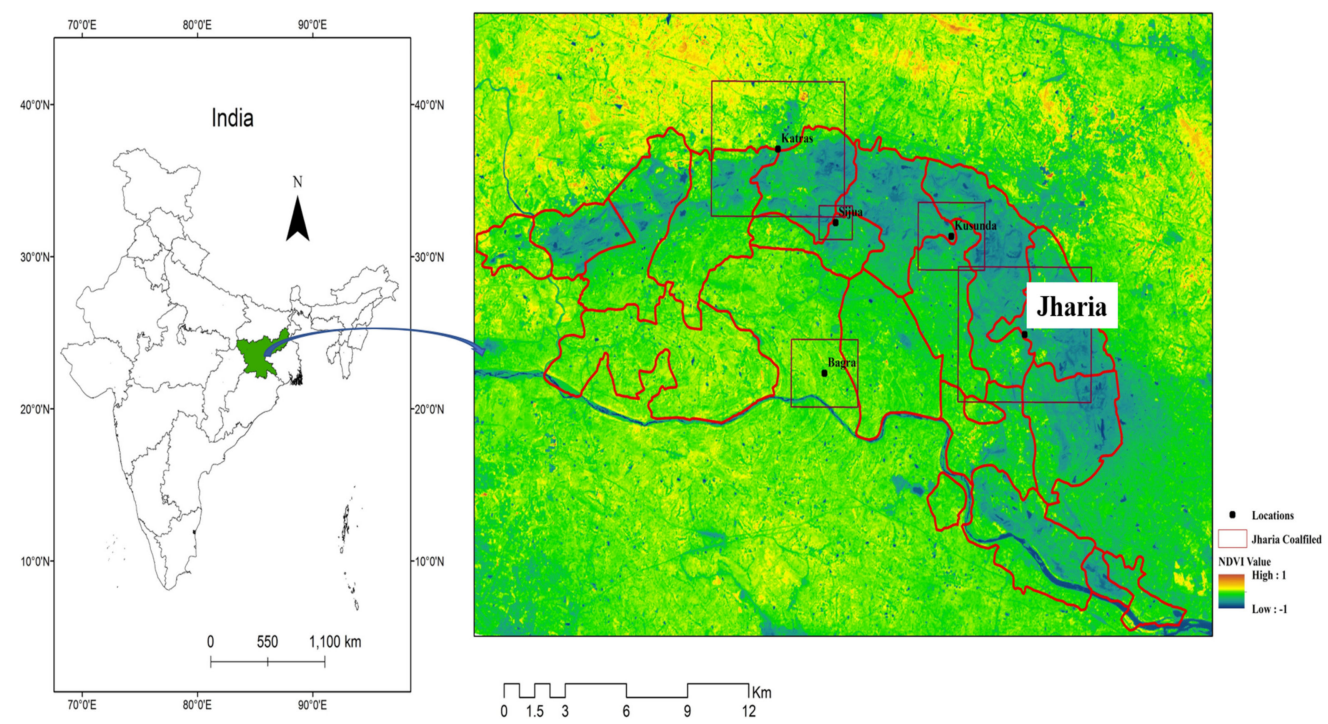

Figure 1. Location of the Jharia Coalfield indicating mined and afforested lands using the normalized difference vegetation index (NDVI) of Bharat Coking Coal Limited (BCCL), Dhanbad, Jharkhand, India.

Jharia coalfield contains proven coal reserves of approximately one billion tonnes, and the major part of it lies in the Dhanbad district (commonly known as the coal capital of India). It is roughly sickle-shaped and characterized by gently undulating to rolling topography. The coal deposits in our study area were from the Barakar Formation. Igneous intrusive occurring in the coalfield is of mica, peridotite, and dolerite types. The Barakar Formation consists of coarse and medium-grained feldspathic sandstone, grits, shales and carbonaceous shales, and coal seam. The maximum depth of work ranged from 80 to $125 \mathrm{~m}$. The general dip of the formation is 10 to 15 degrees. The coalfield covers a total area of $400 \mathrm{~km}^{2}$ of which $140 \mathrm{~km}^{2}$ was under forest and vegetation cover, and $12.5 \mathrm{~km}^{2}$ were barren overburden dumps. Surface mining was carried out using a shovel-dumper combination to extract coking coal. Surface topsoil was removed and over- and inner burden rocks were dumped outside the quarry area. After reaching the stipulated height, overburden dumps were technically reclaimed by leveling, benching, and slop formation approximately to the original contour level. Large rock fragments present in mine spoils were regraded and after topsoil blanketing planted with perennial grasses. Surface mined land that was reclaimed and afforested approximately 8 years before and nearby a natural forest (reference site) was selected for this study. The natural forest soils were lateritic types having greater concentrations of iron and alumina. The natural forest present in the study area was tropical dry deciduous forest having Shorea robusta Roth. tree as a dominant species. The soil in the afforested area was well mixed with the overburden rocks and coal residues. Mine soils contain significant amounts of artifacts and are termed Technosols [26].

\subsection{Vegetation Sampling and Biomass Stock}

Vegetation sampling was carried out at the afforested coal mine land and the reference natural forest sites by randomly laying seven $10 \mathrm{~m} \times 10 \mathrm{~m}$ quadrates under each plant species cover. A total of 28 quadrats were studied for tree species abundance, density, diameter at breast height (DBH), and height. Tree DBH was measured using a Vernier caliper at $1.37 \mathrm{~m}$ above ground level, and tree height was measured using a distometer (Bosch GLM 40, Bengaluru, India). Plant aboveground biomass (AGB) was estimated using an improved allometric equation [27]:

$$
\mathrm{AGB}_{\text {est }}=0.0673 \times\left(\rho \mathrm{D}^{2} \mathrm{H}\right)^{0.976}
$$


where $\mathrm{AGB}_{\text {est }}$ is aboveground biomass $(\mathrm{kg}), \rho$ is wood density $\left(\mathrm{g} \cdot \mathrm{cm}^{-3}\right), \mathrm{D}$ is the diameter at breast height $(\mathrm{cm})$, and $\mathrm{H}$ is the height of the tree $(\mathrm{m})$.

Tree belowground biomass (BGB) can be estimated by the real-time measurement or by using standard allometric equations. Cairns et al. [28] formulated regression equations to estimate root biomass based on AGB carbon in tropical, temperate, and boreal forests and found a mean root-to-shoot (RS) ratio of $0.26(0.18-0.30)$, stating that the most of the root biomass (heavy roots $>2 \mathrm{~mm}$ diameter) is close to $20 \%$ of the total AGB. Similarly, MacDicken [29] proposed that the ratio of BGB to AGB in forests is about 0.20, depending on the species. Fonseca et al. [30] and Intergovernmental Panel on Climate Change (IPCC) [31] assume the root biomass is $25 \%$ of the total AGB. Here, due to the strict rules of the forest department, we were unable to uproot the trees to estimate the BGB. Indirect estimation of the belowground biomass may overestimate the biomass content. It is also important to consider that each species has a specific growth characteristic, and using a similar equation to estimate root biomass for all the trees may provide erroneous results. Here, the BGB $\left(\mathrm{Mg} \cdot \mathrm{ha}^{-1}\right)$ was calculated using the IPCC allometric equation for the tropical ecosystem [32]:

$$
\mathrm{BGB}=\exp [-1.0587+0.8836 \times \ln (\mathrm{AGB})]
$$

where BGB is belowground biomass and AGB is aboveground biomass.

Tree biomass stock was converted to carbon stock using the conversion factor of 0.47 [33]. The corresponding amount of $\mathrm{CO}_{2}$ sequestered $\left(\mathrm{Mg} \cdot \mathrm{ha}^{-1}\right)$ by the plant and soils was calculated by the ratio of $\mathrm{C}$ in the $\mathrm{CO}_{2}$ (3.666). To determine the net ecosystem carbon stock, total carbon sequestered by the system was subtracted from the total carbon emission by the system.

\subsection{Soil Sampling and Analysis}

Soil samples were collected at 0-30-cm depth from all the afforested and natural forest sites following the randomized block design sampling technique. A total of seven sampling quadrates $(10 \mathrm{~m} \times 10 \mathrm{~m})$ which were established for vegetation sampling was also used to collect soil samples, and from each quadrate five sub-samples were collected to make a composite sample. Thus, a sum of 28 composite soil samples (seven from each rhizosphere $\mathrm{x}$ four plant species) was collected and analyzed for soil physicochemical characteristics. To estimate bulk density, soil cores were separately collected from each site using a stainless steel soil corer (8-cm internal diameter and 30-cm tall).

Soil samples were air-dried at room temperature $\left(25-30^{\circ} \mathrm{C}\right)$ for a week before analysis. Coarse rock was separated manually, and soils were gently crushed using mortar and pestle. Fine earth material $(<2 \mathrm{~mm})$ was separated from coarse materials by passing through a 2-mm sieve. Samples were oven-dried at $105^{\circ} \mathrm{C}$ for $48 \mathrm{~h}$ to determine soil moisture content gravimetrically. The percentage of sand, silt, and clay were estimated by the pipette method using $\left(\mathrm{NaPO}_{3}\right)_{6}$ as a dispersing reagent [34]. Soil bulk density was determined by measuring the mass of the oven-dried soil in a known volume of the metallic core and corrected for a coarse fraction $(>2 \mathrm{~mm})$ as described by Ahirwal and Maiti [24]. Soil $\mathrm{pH}$ was determined in a soil: deionized water suspension $(1: 2.5, \mathrm{w} / \mathrm{v})$, using a multi-parameter $\mathrm{pH}$ probe. Soil organic matter (SOM) was estimated as a weight difference after a loss on ignition (LOI) between $105^{\circ} \mathrm{C}$ and $375^{\circ} \mathrm{C}$. Soil organic carbon (SOC) concentration in natural forest soil was analyzed by the rapid dichromate oxidation method [35], and SOC concentrations in afforested coal mine soil were determined by the carbon fractionation method as described by Das and Maiti [36]. Briefly, carbonates free soil residue was treated with $20 \mathrm{~mL}$ of $0.5 \mathrm{M} \mathrm{NaOH}(1: 10 ; \mathrm{w} / \mathrm{v})$ and allowed to react for $1 \mathrm{~h}$ in an orbital shaker, centrifuged at $3000 \mathrm{rpm}$, and the supernatant was discarded. The recovered soil residues were mixed with $20 \mathrm{~mL}$ of $60 \% \mathrm{HNO}_{3}(1: 10 ; \mathrm{w} / \mathrm{v})$ for $15 \mathrm{~min}$ in an orbital shaker. Samples were centrifuged and the supernatant was discarded repeatedly. To extract mineral bound $\mathrm{C}$, the remaining residues were treated with $20 \mathrm{~mL}$ of $10 \% \mathrm{HF}(1: 10 ; \mathrm{w} / \mathrm{v})$ and allowed to react for $4 \mathrm{~h}$ with occasional stirring. Oven-dried residues were treated with $20 \mathrm{~mL}$ of $0.5 \mathrm{M} \mathrm{NaOH}$ (1:10; $\mathrm{w} / \mathrm{v}$ ) for $30 \mathrm{~min}$. The residues were recovered by centrifugation, and samples were washed with 
deionized water, dried at $60{ }^{\circ} \mathrm{C}$ for $48 \mathrm{~h}$ thereafter, and soil residues were ignited at $350{ }^{\circ} \mathrm{C}$ for $3 \mathrm{~h}$. The difference between the amount of carbon present in the carbonate-free soils and after the ignition was considered as the soil organic carbon. The semi-automatic nitrogen estimation system estimated plant-available nitrogen $(\mathrm{N})$ after digesting with $0.32 \% \mathrm{KMnO}_{4}$ solution and titration with $0.02 \mathrm{~N}$ $\mathrm{H}_{2} \mathrm{SO}_{4}$ [37] while total nitrogen (TN) concentration was quantified using an elemental analyzer (Euro EA3000, EuroVector, Redavalle (PV), Italy). Available phosphorus (P) in acidic and alkaline soils was determined as described by Bray and Kurtz [38] and Olsen and Sommers [39], respectively, using a UV-VIS spectrophotometer (UV-1800, Shimadzu Corporation, Kyoto, Japan).

\subsection{Soil $\mathrm{CO}_{2}$ Flux Measurement}

Soil $\mathrm{CO}_{2}$ flux was recorded in situ at each of the tree rhizospheres using the LICOR LI-8100 automated soil $\mathrm{CO}_{2}$ flux system (LICOR Inc. Lincoln, NE, USA). The PVC soil collar, 10-cm tall with a $20-\mathrm{cm}$ internal diameter, was inserted $5 \mathrm{~cm}$ into the soil $24 \mathrm{~h}$ before the start of the first measurement and remained fixed throughout the observations. Biological components observed inside the collar were removed before the start of observation. Soil $\mathrm{CO}_{2}$ flux was recorded at every 15-min interval for $90 \mathrm{~s}$ in a similar atmospheric condition at all of the recording stations. The procedure was repeated for three different seasons (summer, winter, and monsoon) for three consecutive days in each season.

\subsection{Calculations of Carbon and Nitrogen Stock}

Soil elemental ( $\mathrm{C}$ and $\mathrm{N}$ ) stock in both afforested and natural forest soils were calculated by considering elemental concentration, corrected bulk density, and soil depth as follows:

$$
\begin{gathered}
\text { SOC stock }\left(\mathrm{Mg} \cdot \mathrm{ha}^{-1}\right)=\mathrm{SOC} \text { conc } \times \mathrm{BD} \times \mathrm{T} \times 100 \\
\text { Total nitrogen stock }\left(\mathrm{Mg} \cdot \mathrm{ha}^{-1}\right)=\mathrm{TN} \text { conc } \times \mathrm{BD} \times \mathrm{T} \times 100
\end{gathered}
$$

where $\mathrm{SOC}_{\text {conc }}$ is soil organic carbon concentration (\%), $\mathrm{TN}$ is total nitrogen concentration (\%), $\mathrm{BD}$ is

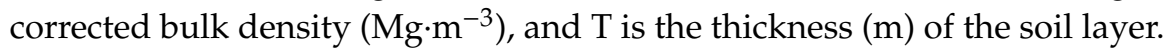

\subsection{Statistical Analysis}

A descriptive statistical analysis (mean and standard deviation) was carried out using the MS Excel package. Homogeneity of variance in the data set was analyzed by the Leven test, and normal distribution in data was analyzed by the Shapiro-Wilk test to pass the primary assumptions associated with the use of one-way analysis of variance (ANOVA). The mean values were compared using ANOVA (with $p<0.05$ considered as significant) and Tukey honest significance difference (HSD) (significance level $\alpha=0.05$ ). Statistical analysis was carried out by SPSS 21.0 (IBM SPSS Statistics for Windows, Version 21.0., IBM Corp., Armonk, NY, USA).

\section{Results}

\subsection{Tree Biomass and Carbon Stock}

Tree biomass and carbon stock of three dominant tree species, namely Albizia lebbeck, Albizia procera, and Dalbergia sissoo of the Fabaceae family, growing on the afforested mine land, were compared with the natural tropical dry deciduous forest dominated by Shorea robusta (Dipterocarpaceae family) (Figure 2). Tree density in the afforested mine land ( 833 trees ha ${ }^{-1}$ ) was greater than the natural forest $\left(400\right.$ trees $\left.\mathrm{ha}^{-1}\right)$. Vegetation characteristics of the afforested trees and natural forest were significantly different in terms of tree height, DBH, AGB, and carbon stock (Table 1). The young age of afforested trees (8 years) at the reclaimed site demonstrated lesser tree growth in comparison to the natural forest. Aboveground biomass of the afforested trees was found in the order of $A$. procera $<$ A. lebbeck $<$ 
D. sissoo. At the afforested site, D. sissoo showed greater biomass stock $\left(83.28 \pm 23.08 \mathrm{Mg} \cdot \mathrm{C} \cdot \mathrm{ha}^{-1}\right)$ thus contributing higher carbon stock compared to A. procera and A. lebbeck (Table 1).

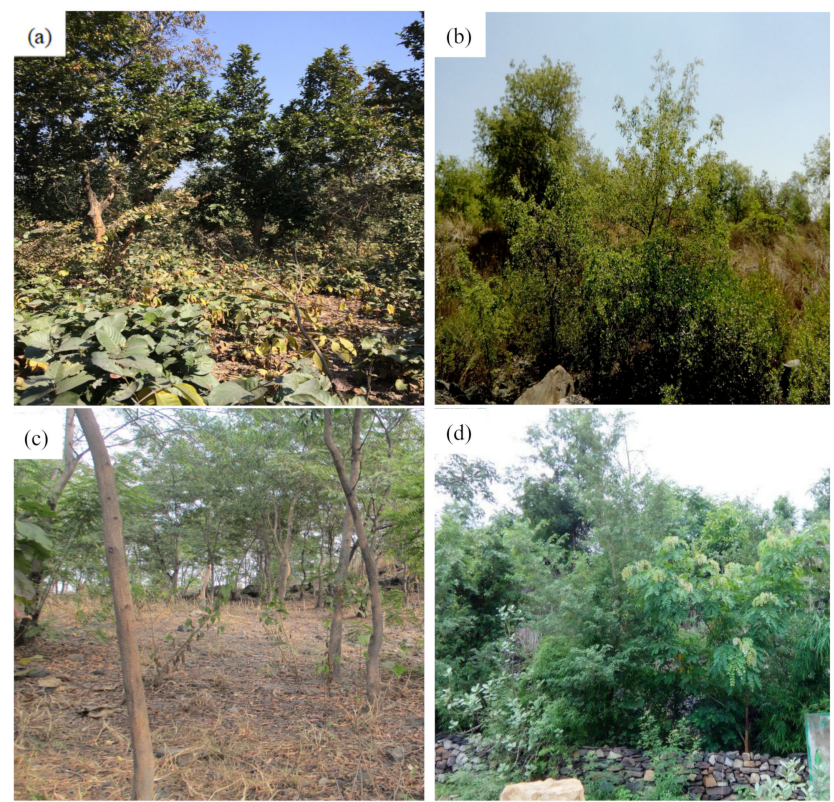

Figure 2. Distance view of the study sites: (a) natural forest showing the dominance of Shorea robusta trees and afforested mine land showing the growth of fast-growing trees (b) Dalbergia sissoo, (c) Albizia lebbeck, and (d) Albizia procera.

Table 1. Vegetation characteristics and accumulation of biomass carbon in a natural forest and afforested trees.

\begin{tabular}{ccccc}
\hline \multirow{2}{*}{ Tree Characteristics } & $\begin{array}{c}\text { Natural Forest } \\
\text { Shorea robusta }\end{array}$ & Albezia lebbeck & Afforested Mine Land \\
& $9.01 \pm 1.31 \mathrm{a}$ & $4.57 \pm 0.53 \mathrm{~b}$ & $4.46 \pm 0.91 \mathrm{~b}$ & $5.52 \pm 1.05 \mathrm{~b}$ \\
& $11.59 \pm 3.25 \mathrm{a}$ & $5.62 \pm 0.68 \mathrm{~b}$ & $5.84 \pm 0.89 \mathrm{~b}$ & $5.88 \pm 0.84 \mathrm{~b}$ \\
Height $(\mathrm{m})$ & $211.49 \pm 114.9 \mathrm{a}$ & $60.67 \pm 19.50 \mathrm{~b}$ & $45.68 \pm 17.86 \mathrm{~b}$ & $68.76 \pm 19.47 \mathrm{~b}$ \\
DBH $(\mathrm{cm})$ & $250.28 \pm 133.5 \mathrm{a}$ & $73.66 \pm 23.18 \mathrm{~b}$ & $55.76 \pm 21.34 \mathrm{~b}$ & $83.28 \pm 23.08 \mathrm{~b}$ \\
AGB $\left(\mathrm{Mg} \cdot \mathrm{ha}^{-1}\right)$ & $117.63 \pm 62.73 \mathrm{a}$ & $34.62 \pm 10.89 \mathrm{~b}$ & $26.21 \pm 10.03 \mathrm{~b}$ & $39.14 \pm 10.85 \mathrm{~b}$ \\
Total biomass $\left(\mathrm{Mg} \cdot \mathrm{ha}^{-1}\right)$ & & &
\end{tabular}

DBH is the diameter at breast height $(1.37 \mathrm{~m})$, AGB is above-ground biomass, different alphabets in the same row indicate significant difference at $p<0.05$ where "a" indicates significantly higher values and " $\mathrm{b}$ " indicates significantly lower values.

\subsection{Soil Characteristics}

Soil physicochemical properties $(0-30 \mathrm{~cm})$ of the afforested mine land under different fast-growing tree species were analyzed and compared with the natural forest. A comparison of mean values using one-way ANOVA showed a significant difference $(p<0.05)$ between the afforested mine soils and natural forest soil (Table 2). Mine soil $\mathrm{pH}$ was slightly alkaline and ranged from 7.30 to 7.48 under different tree species whereas natural forest soil was acidic. Adverse soil conditions in afforested mine land retained less moisture content compared to the natural forest soil. Gravel-free bulk density was significantly greater in the natural forest soils and non-significantly different in afforested mine soils. Changes in fine earth material $(<2 \mathrm{~mm})$ were non-significant in afforested mine soils, but soil under D. sissoo showed slightly greater values. Afforested mine soils were categorized as loamy sand, and natural forest soil was sandy loam. Significant differences in the granulometric parameters were observed between the forest and afforested mine soils, and clay content in the natural forest soil was 2 -fold greater than the afforested mine soils. 
Table 2. Changes in soil physicochemical properties after afforestation of reclaimed mine land with different fast-growing trees and natural forest.

\begin{tabular}{|c|c|c|c|c|c|}
\hline Soil Properties & $\begin{array}{l}\text { Natural Forest } \\
\text { Shorea robusta }\end{array}$ & Albezia lebbeck & $\begin{array}{l}\text { Afforested Mine Land } \\
\text { Albezia procera }\end{array}$ & Dalbergia sissoo & $p$-Value \\
\hline $\mathrm{pH}(1: 2.5)$ & $5.23 \pm 0.38 b$ & $7.36 \pm 0.25 a$ & $7.48 \pm 0.23 a$ & $7.30 \pm 0.26 a$ & $<0.001$ \\
\hline Moisture (\%) & $7.20 \pm 0.56 a$ & $4.08 \pm 0.35 c$ & $4.46 \pm 0.15 c$ & $5.41 \pm 0.37 \mathrm{~b}$ & $<0.001$ \\
\hline Bulk density $\left(\mathrm{Mg} \mathrm{ha}^{-3}\right)$ & $1.54 \pm 0.09 a$ & $0.92 \pm 0.04 b$ & $0.87 \pm 0.05 b$ & $0.90 \pm 0.06 \mathrm{~b}$ & $<0.001$ \\
\hline Fine earth material (\%) & $87.99 \pm 2.05 a$ & $53.54 \pm 3.42 b$ & $54.60 \pm 3.38 b$ & $56.29 \pm 2.49 b$ & $<0.001$ \\
\hline Sand (\%) & $74.43 \pm 1.59 c$ & $82.00 \pm 1.77 \mathrm{a}$ & $79.14 \pm 0.99 b$ & $82.14 \pm 2.10 \mathrm{a}$ & $<0.001$ \\
\hline Silt (\%) & $13.43 \pm 1.68 \mathrm{ab}$ & $11.99 \pm 1.94 b$ & $15.21 \pm 0.75 a$ & $12.34 \pm 1.73 b$ & 0.008 \\
\hline Clay (\%) & $11.54 \pm 2.46 a$ & $5.96 \pm 0.64 b$ & $5.44 \pm 0.70 b$ & $5.53 \pm 1.19 b$ & $<0.001$ \\
\hline Soil organic matter (\%) & $4.02 \pm 0.59 a$ & $2.45 \pm 0.45 b$ & $2.17 \pm 0.50 \mathrm{~b}$ & $3.09 \pm 0.95 \mathrm{ab}$ & $<0.001$ \\
\hline Soil organic carbon (\%) & $1.54 \pm 0.30 \mathrm{a}$ & $0.87 \pm 0.05 b c$ & $0.86 \pm 0.07 c$ & $1.12 \pm 0.08 b$ & $<0.001$ \\
\hline Total nitrogen $(\%)$ & $0.22 \pm 0.01 \mathrm{a}$ & $0.15 \pm 0.01 b$ & $0.12 \pm 0.01 \mathrm{c}$ & $0.14 \pm 0.01 b$ & $<0.001$ \\
\hline $\begin{array}{l}\text { Available nitrogen } \\
\left(\mathrm{mg} \cdot \mathrm{kg}^{-1}\right)\end{array}$ & $98.74 \pm 11.1^{*}$ & $104.3 \pm 14.6^{*}$ & $100.8 \pm 4.99^{*}$ & $94.14 \pm 9.69^{*}$ & 0.431 \\
\hline $\begin{array}{l}\text { Available phosphorous } \\
\left(\mathrm{mg} \cdot \mathrm{kg}^{-1}\right)\end{array}$ & $3.17 \pm 0.59 a$ & $2.23 \pm 0.23 b$ & $2.00 \pm 0.29 b$ & $3.04 \pm 0.49 a$ & $<0.001$ \\
\hline
\end{tabular}

Different alphabets in the same row indicate a significant difference at $p<0.05$ where "a" indicates a significantly higher value, " $b$ " indicates significantly lower values than " $a$ " and significantly higher than the " $c$ ", and " $c$ " indicates significantly lower values. The letters "ab" denote value which is neither significantly different from "a" nor " $b$ ". Insignificantly different values are indicated by "*".

Soil physicochemical parameters and nutrient concentrations were significantly different between the afforested and natural forest soils except for plant-available N (Table 2). Significantly higher SOM concentration was found in the natural forest soils in comparison to afforested mine soils which showed higher SOM concentration under D. sissoo compared to A. lebbeck and A. procera. Similarly, SOC concentration was higher in the natural forest soils and found in the order of $A$. procera $<A$. lebbeck $<D$. sissoo $<$ S. robusta. Natural forest soils showed significantly greater TN concentration compared to the afforested mine soils. However, plant-available $\mathrm{N}$ concentration was non-significantly different but slightly higher in the afforested mine soils, and greater concentration was observed under A. lebbeck. Phosphate concentration was significantly higher in the soils of S. robusta and D. sissoo.

\subsection{Soil Carbon and Nitrogen Stocks}

Soil organic carbon (SOC) and TN stocks in afforested mine soils and natural forest soil were significantly different where natural forest soils demonstrated 3- to 4-fold greater elemental stock than the mine soils (Figure 3). The growth of three dominant tree species at the afforested mine land accumulated a significant amount of SOC stock, but soils under D. sissoo showed a greater amount of SOC stock compared to A. lebbeck and A. procera. However, after eight years of afforestation, mine soils under $D$. sissoo were significantly lower than $S$. robusta at the forest site. Total nitrogen stock in two fast nitrogen-accumulating trees $A$. lebbeck and A. procera was significantly different, however, S. robusta at the forest site showed significantly greater TN stock. The TN stock was found in the order of $A$. procera $<$ D. sissoo $<$ A. lebbeck $<$ S. robusta.

\subsection{Soil $\mathrm{CO}_{2}$ Flux and Ecosystem $\mathrm{CO}_{2}$ Storage}

Variations in soil $\mathrm{CO}_{2}$ flux in afforested mine land and the natural forest site are shown in Figure 4. Soil $\mathrm{CO}_{2}$ flux was significantly higher under $A$. lebbeck $\left(3.10 \pm 0.30 \mu \mathrm{mol} \mathrm{CO} \mathrm{CO}^{-2} \cdot \mathrm{s}^{-1}\right)$ and A. procera $\left(2.83 \pm 0.44 \mu \mathrm{mol} \mathrm{CO} \mathrm{m}^{-2} \cdot \mathrm{s}^{-1}\right)$ while D. sissoo $\left(2.31 \pm 0.17 \mu \mathrm{mol} \mathrm{CO} \mathrm{Cm}^{-2} \cdot \mathrm{s}^{-1}\right)$ showed lower $\mathrm{CO}_{2}$ flux in an afforested mine land. In contrast, natural forest ( $S$. robusta) showed a significantly lower rate of soil $\mathrm{CO}_{2}$ flux $\left(1.27 \pm 0.12 \mu \mathrm{mol} \mathrm{CO} \mathrm{m}^{-2} \cdot \mathrm{s}^{-1}\right)$ in all the studied plant species. 

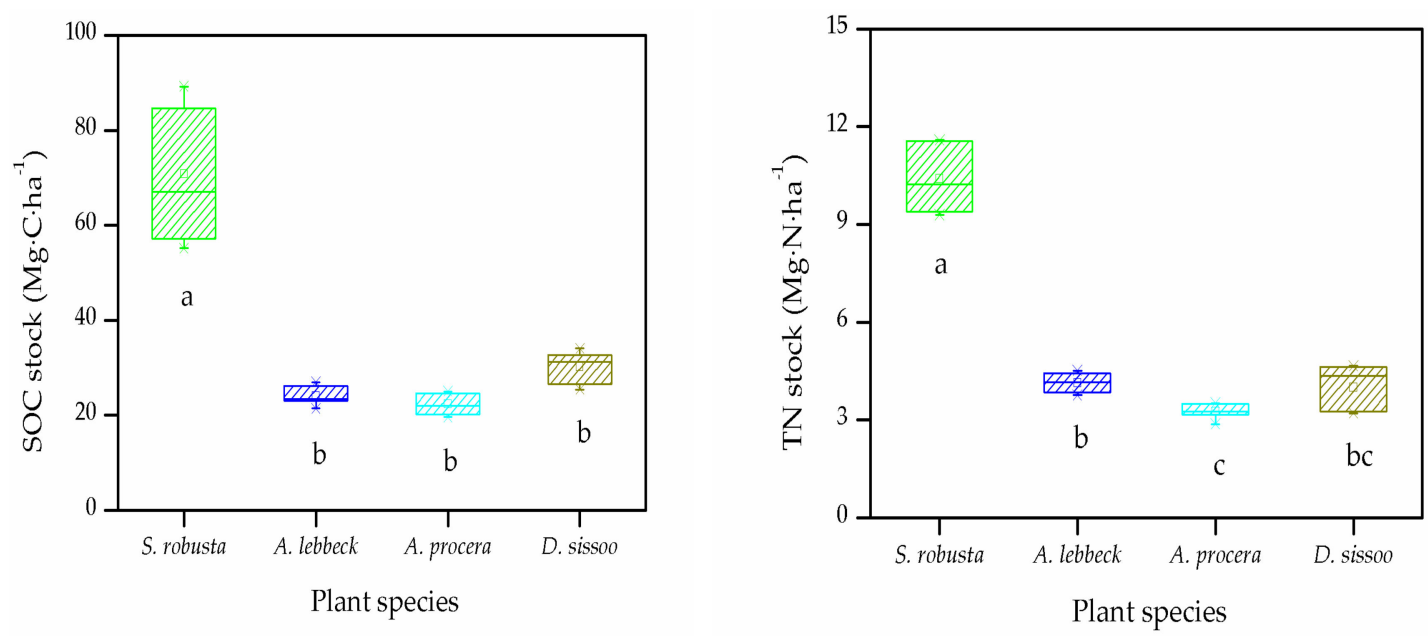

Figure 3. Variations in soil organic carbon (SOC) and total nitrogen (TN) stock under different plant species in the natural forest (Shorea robusta) and afforested trees (Albizia lebbeck, Albizia procera, and Dalbergia sissoo). (Box represents the interquartile range of the data set, and the upper and lower limits of the box show the first quartile and third quartile of the data. Middle line and dot show median and mean value, respectively. Whiskers represent the upper and lower range of the data). Different letters $(\mathrm{a}, \mathrm{b}, \mathrm{c})$ indicate a significant difference at $p<0.05$, where "a" indicates a significantly higher value, and " $b$ " indicates significantly lower values for the SOC stock. The letter " $a$ " indicates significantly higher values, and " $c$ " indicates significantly lower values for TN stock, whereas the letter " $b$ " denotes values which are significantly lower than "a" and significantly higher than " $c$ ". Letters "bc" indicate insignificantly different values from " $b$ " and " $c$ ".

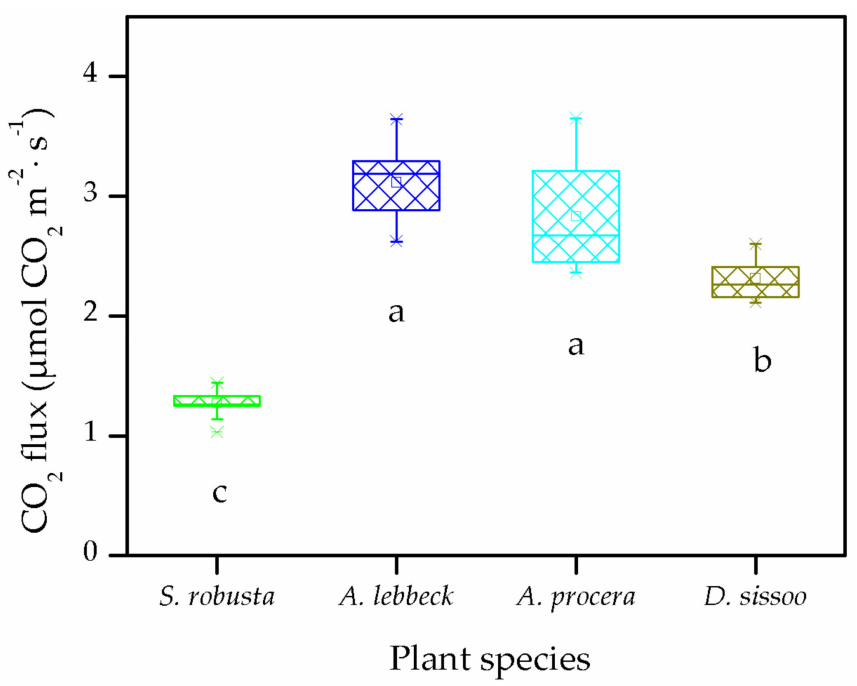

Figure 4. Variation in soil $\mathrm{CO}_{2}$ flux $\left(\mu \mathrm{mol} \mathrm{CO} \mathrm{CO}^{-2} \cdot \mathrm{s}^{-1}\right)$ under natural forest (Shorea robusta) and afforested mine land (Albizia lebbeck, Albizia procera, and Dalbergia sissoo). (Box represents the interquartile range of the data set, and the upper and lower limits of the box show the first quartile and third quartile of the data. Middle line and dot show median and mean value, respectively. Whiskers represent the upper and lower range of the data). Different letters $(a, b, c)$ indicate a significant difference at $p<0.05$, where " $a$ " indicates a significantly higher value, " $b$ " indicates values which are significantly lower than "a" but significantly higher than " $c$ ", and " $c$ " alone indicates a significantly lower value $(p<0.001)$.

The total ecosystem carbon pool (carbon sequestered by the plant biomass and soils) was determined in terms of $\mathrm{CO}_{2}$ equivalent. After eight years of afforestation, the results of our study show less amount of carbon sequestered by the afforested mine land compared to the natural forest site. 
In terms of soil $\mathrm{CO}_{2}$ flux, afforested mine land releases a greater amount of $\mathrm{CO}_{2}$ into the atmosphere where $A$. lebbeck releases more $\mathrm{CO}_{2}$ compared to other tree species.

\section{Discussion}

\subsection{Effect of Afforestation on Mine Soil}

Reclamation of the post-mining ecosystem to achieve the pre-disturbed conditions is a challenging task for land managers and restoration ecologists. A suite of studies has reported various efforts to reclaim post-mining land, of which afforestation is widely used to restore a mine-degraded ecosystem [6,10,40,41]. Afforestation plays a constructive role in the reclamation of mine spoil because it modifies the soil characteristics and accelerates the soil redevelopment by contributing above- and below-ground biomass to soils [42]. The present study analyzed the effect of afforestation of mine-degraded land using fast-growing tree species and showed a significant impact on the soil properties after eight years of afforestation. As in other studies [43-45], we found a positive effect of afforestation of mine soils, but we also observed different potentials of fast-growing trees to reclaim mine-degraded land. Overburden materials (mine spoil) contain a greater amount of rocks that are regraded to some extent during technical reclamation. Thus, mine soils demonstrate high rock fraction and lesser fine earth materials whereas natural forest soil shows greater fine earth fraction attributed to its geological formations. Leveling of dump surface and land preparation for further use increases the movement of heavy earth-moving vehicles that compact mine soils, reduce soil moisture, and increase bulk density. We considered only fine earth materials to determine soil bulk density, therefore a higher amount of coarse fraction present in mine soils was eliminated which decreased the bulk density values of the mine soils. Mining and reclamation techniques significantly alter soil texture, particularly clay content. Application of fertile topsoil before afforestation of mine dump, rhizodeposits, and decomposition of plant litter along with the age of afforestation may alter the mine soil $\mathrm{pH}$.

Surface mined land has been subjected to various physicochemical and biological alterations such as a change in soil structure and loss of organic matter and nutrients which altogether affect the mine soil functions [5]. The loss of SOM during the surface mining activities and their accretion during the reclamation process play an essential role in mine soil fertility. We found $30-85 \%$ lesser SOM concentration in afforested mine soils compared to natural forest soils. There has been a massive loss of SOM during the stockpiling that is attributable to topsoil removal and lack of fresh $C$ input [46]. Similarly, available P concentration in mine soils under different tree species decreases up to $4-58 \%$ compared to natural forest soils which may be correlated with the soil $\mathrm{pH}$ that is acidic in natural forest soils and alkaline in afforested mine soil. The greatest phosphorus availability was recorded in circumneutral $\mathrm{pH}$. In acidic soils, greater availability of $\mathrm{Fe}$ and $\mathrm{Al}$ makes insoluble phosphate compounds in the soil. In contrast, the growth of nitrogen-fixing trees (A. lebbeck and A. procera) on afforested mine land increased the plant-available $\mathrm{N}$ concentration, but the differences between the afforested and natural forest soils were non-significant. However, long-term accumulation and N-mineralization increased TN concentrations in natural forest soils. The effect of planting leguminous trees on mine tailings after two to four decades creates islands of fertility by accretion of soil nutrients such as mineral N, TN, and SOM [20]. Planting leguminous tree species in the early stages of post-mining reclamation showed a positive effect on soil fertility and accumulated $0.10 \%$ $\mathrm{N}$ concentration after nine years of afforestation of coal mine soil in Indonesia [47]. In addition, planting $\mathrm{N}$-fixing legumes on former mine land increases the available $\mathrm{N}$ concentration by $79 \%$ and TN by $62 \%$ compared to topsoil without plantation [21]. In comparison to natural forest, we found the significant recovery of TN stocks (31-40\%) in mine soils after eight years of afforestation. Our results show the promising effect of planting $\mathrm{N}$-fixing trees that not only enhance nitrogen concentration but also increase soil fertility of the former mine land. The differences between the soil physicochemical properties of the natural forest soils and afforested mine soil are mainly attributable to the mining and reclamation activities. 


\subsection{Carbon Storage in Plant and Soil}

As in other studies [7,25], we found that carbon stock in plant AGB and BGB increases after eight years of afforestation, and D. sissoo showed greater carbon storage compared to A. lebbeck and A. procera growing at the mine land. On the other hand, S. robusta in the natural forest stored $117.63 \mathrm{Mg} \cdot \mathrm{C} \cdot \mathrm{ha}{ }^{-1}$ which is greater than the afforested site. A study of early tree growth at the reclaimed coal mine site in Appalachia, USA, reported a 50\% lower growth compared to the native forest [22]. Growth of the afforested tree species along the afforestation age increases the potential for carbon storage in phytomass. The afforested site after eight years of plant growth recovered up to $85 \%$ of the biomass carbon stored in the natural forest. It is noteworthy that although the species density was higher in the afforested site, biomass carbon stock was recorded higher in the natural forest. Biomass carbon storage in $D$. sissoo at the reclaimed coal mine in India reported $50.77 \mathrm{Mg} \cdot C \cdot \mathrm{ha}^{-1}$ after 16 years of afforestation [25]. Estimates of carbon sequestration in four-years-old A. lebbeck dominated afforested mine land stored $7.82 \mathrm{Mg} \cdot \mathrm{C} \cdot \mathrm{ha}^{-1}$ [36]. The differences between the carbon storage values of the afforested trees can be ascribed by the variations in soil substrates, prevailing climate conditions, and growth characteristics of the individual tree species.

Soils under D. sissoo plantation had greater SOC concentration compared to other trees growing at the afforested site, however, natural forest soils showed significantly higher SOC concentration that was $27-79 \%$ greater than the afforested mine soils. Similar to biomass carbon stock, the differences in SOC stock under various tree species at the afforested site were non-significant but soils under $D$. sissoo stored greater SOC stock in the top 30-cm soils. Planting fast-growing tree species on reclaimed mine sites showed a varied amount of SOC stock that was up to 2- to 3-fold lesser than the S. robusta. Since the soil substrate remains the same under different tree species, the difference in SOC stocks under afforested trees may be ascribed by the amount of litter, decomposition of dead roots, and elemental composition of the individual biomass. Furthermore, the difference in bulk density, soil moisture content, and soil texture has shown a remarkable effect of SOC stock in afforested mine soil [48]. A suite of studies conducted in reclaimed coal mine soils reported a range of SOC stocks that are comparable to natural forests. For instance, the growth of N-fixing Alnus sp. on Technosol since 10 years of afforestation stored $45.45 \mathrm{Mg} \cdot \mathrm{C} \cdot \mathrm{ha}^{-1}$ in the top 30-cm soils [49]. Accretion of SOC stock in coal mine land showed 45.4 Mg.C.ha ${ }^{-1}$ after eight years of forestation with Prosopis juliflora [50]. Our study showed a significant amount of SOC storage in mine soils after eight years of afforestation. Higher SOC sequestration rate in afforested mine land indicates that the afforested ecosystem accumulates a greater amount of atmospheric $\mathrm{CO}_{2}$ in a short duration thus helping in offsetting increased $\mathrm{CO}_{2}$ into the atmosphere.

\subsection{Effect of Afforestation on Ecosystem Carbon Pool}

We estimated ecosystem carbon pool by combining carbon storage in both plant biomass and top 30-cm soils and found a greater ecosystem carbon pool in natural forest. Under different afforested trees and natural forests, a greater ecosystem carbon pool was found in natural forest $\left(188.43 \mathrm{Mg} \cdot \mathrm{C} \cdot \mathrm{ha}^{-1}\right)$, and afforested mine land showed comparable recovery of ecosystem carbon pool $\left(176.55 \mathrm{Mg} \cdot \mathrm{C} \cdot \mathrm{ha}{ }^{-1}\right)$ after eight years of plant growth. Assessment of the effect of tree plantation on ecosystem carbon pool in acid and metal impacted landscape reported carbon storage at $55-136 \mathrm{Mg} \cdot \mathrm{C} \cdot \mathrm{ha}^{-1}$ that increases at a rate of $1.70 \mathrm{Mg} \cdot \mathrm{C} \cdot \mathrm{ha}^{-1} \cdot \mathrm{yr}^{-1}$ [51]. The relative contribution to ecosystem carbon pool by plant and soil showed a varied amount of carbon pool in afforested and forest ecosystems. Of the total carbon stored in afforested mine land, plant contributed $56 \%$ and soil contributed $43 \%$. In a natural forest, plant constitutes $62 \%$ of carbon and soil constitutes $37 \%$ of carbon in the total ecosystem carbon pool.

The present study also estimated total soil $\mathrm{CO}_{2}$ efflux under afforested mine land and natural forest and showed greater $\mathrm{CO}_{2}$ emissions from afforested mine soils. Greater soil $\mathrm{CO}_{2}$ flux under A. lebbeck followed by $A$. procera and $D$. sissoo indicates higher carbon turnover under $A$. lebbeck while greater carbon accumulation in soil under $D$. sissoo. Comparative analysis of the soil $\mathrm{CO}_{2}$ flux under different afforested trees showed that $A$. lebbeck releases a $65 \%$ greater amount of $\mathrm{CO}_{2}$ compared to $D$. sissoo while it was more than double that of reported for S. robusta in natural forest. Although A. lebbeck 
and $A$. procera showed higher soil $\mathrm{CO}_{2}$ flux, they are insignificantly different. Soil $\mathrm{CO}_{2}$ efflux is a combined effect of rhizospheric respiration that includes root and associated mycorrhizae and microbial respiration that may vary with the plant species, climatic conditions, and soil substrates [52]. Mine soils contain a large percentage of coal particles which were mixed during overburden dumping and reclamation activities [36]. These coal particles absorbed heat from the atmosphere and get oxidized to produce $\mathrm{CO}_{2}$. Additionally, the burning of coal shells is a dominant non-biological source of mine soil $\mathrm{CO}_{2}$ flux [53]. The variation in soil $\mathrm{CO}_{2}$ flux was also attributable to the differences in the temperature of both soil types. In a natural forest, the development of canopy cover and greater tree growth formed the shed that resulted in lower soil temperature that in turn decreased the $\mathrm{CO}_{2}$ flux. On the other hand, the younger age of afforested trees showed comparatively lesser canopy cover that helped to absorb sunlight and increased mine soil temperature. The results of our study are in agreement with the previously published work in the similar climatic conditions that reported greater soil $\mathrm{CO}_{2}$ flux in afforested mine soils compared to natural forests [7,53]. Mathiba et al. [54] reported soil $\mathrm{CO}_{2}$ efflux in reclaimed coal mine soil in a range of 2.36-2.98 $\mu \mathrm{mol} \mathrm{CO} \mathrm{CO}^{-2} \cdot \mathrm{s}^{-1}$ in a humid continental climate in the United States. In a dry tropical climate, Mukhopadhyay and Maiti [55] reported soil $\mathrm{CO}_{2}$ efflux $5.70 \mu \mathrm{mol} \mathrm{CO} \mathrm{Cm}^{-2} \cdot \mathrm{s}^{-1}$ in afforested land and $2.17 \mu \mathrm{mol} \mathrm{CO}_{2} \mathrm{~m}^{-2} \cdot \mathrm{s}^{-1}$ in coal mine reclaimed land. Similarly, Ahirwal et al. [7] reported $2.36 \mu \mathrm{mol} \mathrm{CO} \mathrm{m}^{-2} \cdot \mathrm{s}^{-1}$ in reclaimed coal mine land in India. Afforestation of former coal mine land stored a significant amount of carbon in plant biomass and soil thus playing an important role in sequestering atmospheric $\mathrm{CO}_{2}$. In terms of $\mathrm{CO}_{2}$ sequestration, the present study showed a greater amount of $\mathrm{CO}_{2}$ storage by natural forest. Results from the present study conclude that planting fast-growing trees on coal mine land accumulate a significant amount of carbon in plant and soil after eight years, but higher soil $\mathrm{CO}_{2}$ efflux reduced the net ecosystem carbon pool.

Although our study successfully demonstrates forestry as land use to recover ecosystem carbon pool, post-mining land-use always carries a legacy of mining. Recent developments in ecosystem restoration research showed that the mining companies or stakeholders have shifted their focus from just planting trees to developing alternative land uses that potentially strengthen the economy and subsidy the cost of mining activities. For example, the development of a fruit orchard on reclaimed mine land [56] and bioenergy plantation [57] can be a potential alternative use of mined areas. To increase biodiversity in afforested mine land, native trees were preferred, but due to initial harsh environmental conditions, fast-growing trees that are stress-tolerant and accumulate greater biomass were used. However, after the initiation of the succession trajectory, native tree species started invading the areas that not only increase the biodiversity and carbon pool but also indicate the ecosystem stability [7]. Such types of multipurpose land use not only reduce the efforts of land managers but also sustainably manage the ecosystem and help to fulfill the objectives of the United Nations Sustainable Development Goals (UN-SDGs) such as economic growth, providing clean energy, and offsetting climate change.

\section{Conclusions}

The study investigated the effect of fast-growing tree species on mine soil properties and carbon storage in post-mining land. After eight years of afforestation, carbon accumulation in plant biomass in different tree species showed a range of carbon stock, and D. sissoo stored the greatest amount of carbon in biomass and soils. A combination of higher carbon-accumulating (Dalbergia sissoo) and nitrogen-fixing (Albizia lebbeck and Albizia procera) fast-growing trees significantly increased SOC and TN stocks in mine soils. Apart from increasing soil $\mathrm{pH}$ and moisture content, afforestation also played a significant role in the accretion of SOM, SOC, and $\mathrm{N}$ in mine soils, and with the increasing age of afforestation, mine soil may demonstrate greater nutrients and SOC pool that are comparable to natural forest soils. Based on the results of our study, we concluded that afforestation of former mine lands with fast-growing trees plays an essential role in the restoration of coal mine-degraded land and increases carbon and nitrogen pool in mine soils. We recommend the use of Dalbergia sissoo, 
Albizia lebbeck, and Albizia procera for afforestation of drastically disturbed mine lands to restore mine soil fertility in a short duration of time.

Author Contributions: J.A. and S.K.M. designed the research; J.A. performed experiments and analyzed data; J.A. and A.K. drafted the initial manuscript; J.A., A.K., and S.K.M. revised and approved the manuscript. All authors gave final approval for publication. All authors have read and agreed to the published version of the manuscript.

Funding: This research received no external funding.

Acknowledgments: The authors would like to thank the Indian Institute of Technology (Indian School of Mines) Dhanbad for providing research facilities and Bharat Coking Coal Limited (BCCL) Dhanbad for providing sites to study. A. Kumar acknowledge the work support by the Ministry of Science and Higher Education of the Russian Federation, (agreement no. 02.A03.21.0006) and RFBR-DST (Project no. 19-516-45006). We also acknowledge the editor and anonymous reviewers for providing insightful comments during the revision process.

Conflicts of Interest: The authors declare no conflict of interest.

\section{References}

1. United Nation Environment Programme (UNEP). 2019. Available online: https://www.unenvironment.org/ news-and-stories/press-release/new-un-decade-ecosystem-restoration-offers-unparalleled-opportunity (accessed on 21 July 2020).

2. International Union for Conservation of Nature (IUCN). 2017. Available online: https://www.iucn.org/sites/ dev/files/content/documents/20170502_iucn-forest-brief-no-17-bonn-challenge-asia_web.pdf (accessed on 25 July 2020).

3. Ministry of Coal, Government of India. 2020. Available online: https://coal.nic.in/sites/upload_files/coal/ files/coalupload/AnnualReport2019-20/Chapter2-en.pdf (accessed on 25 July 2020).

4. Feng, Y.; Wang, J.; Bai, Z.; Reading, L. Effects of surface coal mining and land reclamation on soil properties: A review. Earth Sci. Rev. 2019, 191, 12-25. [CrossRef]

5. Macdonald, S.E.; Landhäusser, S.M.; Skousen, J.; Franklin, J.; Frouz, J.; Hall, S.; Jacobs, D.F.; Quideau, S. Forest restoration following surface mining disturbance: Challenges and solutions. New For. 2015, 46, 703-732. [CrossRef]

6. Zipper, C.E.; Burger, J.A.; Skousen, J.G.; Angel, P.N.; Barton, C.D.; Davis, V.; Franklin, J.A. Restoring forests and associated ecosystem services on Appalachian coal surface mines. Environ. Manag. 2011, 47, 751-765. [CrossRef]

7. Ahirwal, J.; Maiti, S.K.; Singh, A.K. Changes in ecosystem carbon pool and soil $\mathrm{CO}_{2}$ flux following post-mine reclamation in dry tropical environment, India. Sci. Total Environ. 2017, 583, 153-162. [CrossRef] [PubMed]

8. Frouz, J.; Dvorščík, P.; Vávrová, A.; Doušová, O.; Kadochová, Š.; Matějíček, L. Development of canopy cover and woody vegetation biomass on reclaimed and unreclaimed post-mining sites. Ecol. Eng. 2015, 84, 233-239. [CrossRef]

9. Prach, K.; Hobbs, R.J. Spontaneous succession versus technical reclamation in the restoration of disturbed sites. Restor. Ecol. 2008, 16, 363-366. [CrossRef]

10. Pietrzykowski, M. Tree species selection and reaction to mine soil reconstructed at reforested post-mine sites: Central and eastern European experiences. Ecol. Eng. 2019, 3, 100012. [CrossRef]

11. Č́žžková, B.; Woś, B.; Pietrzykowski, M.; Frouz, J. Development of soil chemical and microbial properties in reclaimed and unreclaimed grasslands in heaps after opencast lignite mining. Ecol. Eng. 2018, 123, 103-111. [CrossRef]

12. Frouz, J.; Vindušková, O. Soil Organic Matter Accumulation in Postmining Sites: Potential Drivers and Mechanisms. In Soil Management and Climate Change; Muñoz, M.A., Zornoza, R., Eds.; Academic Press: Cambridge, MA, USA, 2018; pp. 103-120.

13. Schimel, D.S. Terrestrial ecosystems and the carbon cycle. Glob. Chang. Biol. 1995, 1, 77-91. [CrossRef]

14. Kirschbaum, M.U. Will changes in soil organic carbon act as a positive or negative feedback on global warming? Biogeochemistry 2000, 8, 21-51. [CrossRef]

15. Jian, J.; Steele, M.K.; Day, S.D.; Thomas, R.Q. Future global soil respiration rates will swell despite regional decreases in temperature sensitivity caused by rising temperature. Earth's Future 2018, 6, 1539-1554. [CrossRef] 
16. Xu, M.; Shang, H. Contribution of soil respiration to the global carbon equation. J. Plant. Physiol. 2016, 203, 16-28. [CrossRef] [PubMed]

17. Bond-Lamberty, B.; Thomson, A. A global database of soil respiration data. Biogeosciences 2010, 7, 1915-1926. [CrossRef]

18. Ghosh, D.; Maiti, S.K. Can biochar reclaim coal mine spoil? J. Environ. Manag. 2020, 272, 111097. [CrossRef] [PubMed]

19. Antonelli, P.M.; Fraser, L.H.; Gardner, W.C.; Broersma, K.; Karakatsoulis, J.; Phillips, M.E. Long term carbon sequestration potential of biosolids-amended copper and molybdenum mine tailings following mine site reclamation. Ecol. Eng. 2018, 117, 38-49. [CrossRef]

20. Nyenda, T.; Gwenzi, W.; Gwata, C.; Jacobs, S.M. Leguminous tree species create islands of fertility and influence the understory vegetation on nickel-mine tailings of different ages. Ecol. Eng. 2020, 155, 105902. [CrossRef]

21. Kumari, S.; Maiti, S.K. Reclamation of coalmine spoils with topsoil, grass, and legume: A case study from India. Environ. Earth Sci. 2019, 78, 429. [CrossRef]

22. Dallaire, K.; Skousen, J. Early tree growth in reclaimed mine soils in appalachia USA. Forests 2019, 10, 549. [CrossRef]

23. Yang, B.; Bai, Z.; Cao, Y.; Xie, F.; Zhang, J.; Wang, Y. Dynamic Changes in Carbon Sequestration from Opencast Mining Activities and Land Reclamation in China's Loess Plateau. Sustainability 2019, 11, 1473. [CrossRef]

24. Ahirwal, J.; Maiti, S.K. Assessment of carbon sequestration potential of revegetated coal mine overburden dumps: A chronosequence study from dry tropical climate. J. Environ. Manag. 2017, 201, 369-377. [CrossRef]

25. Mukhopadhyay, S.; Masto, R.E. Carbon storage in coal mine spoil by Dalbergia sissoo Roxb. Geoderma 2016, 284, 204-213. [CrossRef]

26. IUSS Working Group WRB. World Reference Base for Soil Resources 2014, Update 2015 International Soil Classification System for Naming Soils and Creating Legends for Soil Maps; World Soil Resources Reports; FAO: Rome, Italy, 2015; Volume 106.

27. Chave, J.; Réjou-Méchain, M.; Búrquez, A.; Chidumayo, E.; Colgan, M.S.; Delitti, W.B.; Duque, A.; Eid, T.; Fearnside, P.M.; Goodman, R.C.; et al. Improved allometric models to estimate the aboveground biomass of tropical trees. Glob. Chang. Biol. 2014, 20, 3177-3190. [CrossRef] [PubMed]

28. Cairns, M.A.; Brown, S.; Helmer, E.H.; Baumgardner, G.A. Root biomass allocation in the world's upland forests. Oecologia 1997, 111, 1-11. [CrossRef] [PubMed]

29. MacDicken, K.G. A Guide to Monitoring Carbon Storage in Forestry and Agroforestry Projects; Winrock International Institute for Agricultural Development: Arlington, VA, USA, 1997; p. 87.

30. Fonseca, W.; Rey Benayas, J.M.; Alice, F.E. Carbon accumulation in the biomass and soil of different aged secondary forests in the humid tropics of Costa Rica. For. Ecol. Manag. 2011, 262, 1400-1408. [CrossRef]

31. Eggleston, S.; Buendia, L.; Miwa, K.; Ngara, T.; Tanabe, K. (Eds.) IPCC Guidelines for National Greenhouse Gas Inventories; Institute for Global Environmental Strategies: Hayama, Japan, 2011.

32. Penman, J.; Gytarsky, M.; Hiraishi, T.; Krug, T.; Kruger, D.; Pipatti, R.; Buendia, L.; Miwa, K.; Ngara, T.; Tanabe, K.; et al. (Eds.) Good Practice Guidance for Land Use, Land-Use Change and Forestry; Institute for Global Environmental Strategies: Hayama, Japan, 2003.

33. Eggleston, S.; Buendia, L.; Miwa, K.; Ngara, T.; Tanabe, K. (Eds.) IPCC Guidelines for National Greenhouse Gas Inventories; Institute for Global Environmental Strategies: Hayama, Japan, 2006.

34. Piper, C.S. Soil and Plant Analysis; Maver Publisher: Bombay, India, 1966.

35. Nelson, D.W.; Sommers, L.E. Total carbon, organic carbon, and organic matter. In Methods of Soil Analysis, Part 3, Chemical Methods, 3rd ed.; SSSA Book Series 5; Sparks, D.L., Page, A.L., Helmke, P.A., Loeppert, R.H., Soltanpour, P.N., Tabatabai, M.A., Johnston, C.T., Sumner, M.E., Eds.; SSSA: Madison, WI, USA, 1996; pp. 961-1010.

36. Das, R.; Maiti, S.K. Importance of carbon fractionation for the estimation of carbon sequestration in reclaimed coalmine soils-A case study from Jharia coalfields, Jharkhand, India. Ecol. Eng. 2016, 90, 135-140. [CrossRef]

37. Subbiah, B.V.; Asija, G.L. A rapid procedure for the determination of available nitrogen in soils. Curr. Sci. 1956, 5, 259-260.

38. Bray, R.; Kurtz, L.T. Determination of total, organic and available forms of phosphorus in soil. Soil Sci. 1966, 59, 39-45. [CrossRef] 
39. Olsen, S.R.; Sommer, L.E. Phosphorus. In Methods of Soil Analysis, Part 2; Page, A.L., Ed.; SSSA: Madison, WI, USA, 1982; pp. 403-430.

40. Józefowska, A.; Sokołowska, J.; Woźnica, K.; Woś, B.; Pietrzykowski, M. Tree species and soil substrate affect buffer capacity of anthroposols in afforested postmine sites in Poland. J. Soil Water Conserv. 2019, 74, 372-379. [CrossRef]

41. Ahirwal, J.; Maiti, S.K. Development of Technosol properties and recovery of carbon stock after 16 years of revegetation on coal mine degraded lands, India. Catena 2018, 166, 114-123. [CrossRef]

42. Skousen, J.; Ziemkiewicz, P.; Venable, C. Tree recruitment and growth on 20-year-old, unreclaimed surface mined lands in West Virginia. Int. J. Surface Mining Reclam. Environ. 2006, 20, 142-154. [CrossRef]

43. Das, R.; Maiti, S.K. Estimation of carbon sequestration in reclaimed coalmine degraded land dominated by Albizia lebbeck, Dalbergia sissoo and Bambusa arundinacea plantation: A case study from Jharia Coalfields, India. Int. J. Coal Sci. Technol. 2016, 3, 246-266. [CrossRef]

44. Asensio, V.; Vega, F.A.; Covelo, E.F. Changes in the phytoavailability of nutrients in mine soils after planting trees and amending with wastes. Water Air Soil Pollut. 2014, 225, 1995. [CrossRef]

45. Cerqueira, B.; Vega, F.A.; Silva, L.F.; Andrade, L. Effects of vegetation on chemical and mineralogical characteristics of soils developed on a decantation bank from a copper mine. Sci. Total Environ. 2012, 421, 220-229. [CrossRef] [PubMed]

46. Banning, N.C.; Grant, C.D.; Jones, D.L.; Murphy, D.V. Recovery of soil organic matter, organic matter turnover and nitrogen cycling in a post-mining forest rehabilitation chronosequence. Soil Biol. Biochem. 2008, 40, 2021-2031. [CrossRef]

47. Woodbury, D.J.; Yassir, I.; Doroski, D.A.; Queenborough, S.A.; Ashton, M.S. Filling a void: Analysis of early tropical soil and vegetative recovery under leguminous, post-coal mine reforestation plantations in East Kalimantan, Indonesia. Land Degrad. Dev. 2020, 31, 473-487. [CrossRef]

48. Zhang, Z.; Wang, J.; Li, B. Determining the influence factors of soil organic carbon stock in opencast coal-mine dumps based on complex network theory. Catena 2019, 173, 433-444. [CrossRef]

49. Woś, B.; Józefowska, A.; Pająk, M.; Chodak, M.; Frouz, J.; Pietrzykowski, M. Carbon and Macronutrient Budgets in an Alder Plantation Grown on a Reclaimed Combustion Waste Landfill. Forests 2020, 11, 430. [CrossRef]

50. Ahirwal, J.; Maiti, S.K.; Reddy, M.S. Development of carbon, nitrogen and phosphate stocks of reclaimed coal mine soil within 8 years after forestation with Prosopis juliflora (Sw.) Dc. Catena 2017, 156, 42-50. [CrossRef]

51. Preston, M.D.; Brummell, M.E.; Smenderovac, E.; Rantala-Sykes, B.; Rumney, R.H.; Sherman, G.; Basiliko, N.; Beckett, P.; Hebert, M. Tree restoration and ecosystem carbon storage in an acid and metal impacted landscape: Chronosequence and resampling approaches. Forest Ecol. Manag. 2020, 463, 118012. [CrossRef]

52. Acosta, M.; Darenova, E.; Krupková, L.; Pavelka, M. Seasonal and inter-annual variability of soil $\mathrm{CO}_{2}$ efflux in a Norway spruce forest over an eight-year study. Agric. For. Meteorol. 2018, 256, 93-103. [CrossRef]

53. Ahirwal, J.; Maiti, S.K. Assessment of soil carbon pool, carbon sequestration and soil $\mathrm{CO}_{2}$ flux in unreclaimed and reclaimed coal mine spoils. Environ. Earth Sci. 2018, 77, 9. [CrossRef]

54. Mathiba, M.; Awuah-Offei, K.; Baldassare, F.J. Influence of elevation, soil temperature and soil moisture content on reclaimed mine land soil $\mathrm{CO}_{2}$ fluxes. Environ. Earth Sci. 2015, 73, 6131-6143. [CrossRef]

55. Mukhopadhyay, S.; Maiti, S.K. Soil $\mathrm{CO}_{2}$ flux in grassland, afforested land and reclaimed coalmine overburden dumps: A case study. Land Degrad. Dev. 2014, 25, 216-227. [CrossRef]

56. Maiti, S.K.; Kumar, A.; Ahirwal, J. Bioaccumulation of metals in timber and edible fruit trees growing on reclaimed coal mine overburden dumps. Int. J. Min. Reclam. Environ. 2016, 30, 231-244. [CrossRef]

57. Ussiri, D.A.; Guzman, J.G.; Lal, R.; Somireddy, U. Bioenergy crop production on reclaimed mine land in the North Appalachian region, USA. Biomass Bioenergy 2019, 125, 88-95. [CrossRef]

(C) 2020 by the authors. Licensee MDPI, Basel, Switzerland. This article is an open access article distributed under the terms and conditions of the Creative Commons Attribution (CC BY) license (http://creativecommons.org/licenses/by/4.0/). 